\title{
The Promotion of Vietnam Foreign Direct Investment
}

\author{
Pham Nguyen My Linh ${ }^{1}$, Nguyen Thi Thu Huong 2 , Nguyen Ngoc Ha ${ }^{2}$, Nguyen Minh Hanh ${ }^{2}$ \\ ${ }^{1}$ Asper School of Business, University of Manitoba, Manitoba, Canada \\ ${ }^{2}$ Academy of Finance, Hanoi, Vietnam \\ Correspondence: Pham Nguyen My Linh, Asper School of Business, University of Manitoba, Manitoba, Canada. \\ E-mail:phamc1@myumanitoba.ca
}

Received: September 2, 2020

doi:10.5539/ijbm.v15n12p62

\author{
Accepted: October 20, 2020 \\ Online Published: November 6, 2020 \\ URL: https://doi.org/10.5539/ijbm.v15n12p62
}

\begin{abstract}
Vietnam is getting deeper and wider in its intergation with international economy, especially after becoming official member of World Trade Organization. This affiliation has benefited Vietnamese enterprises in being treated fairly on worldwide playground. Recently, they have realized there are a lot of oppotunities foreign direct investment. They also cooperate in adjusting Vietnamese State's conception of offshore funding. This article concentrates in analyzing the fact of foreign direct investment of Vietnamese businesses, points out its achievements, disadvantages and reasons for limits, thus, makes an offer for the promomtion of Vietnamese enterprises to invest abroad directly in the context of world economic integration.
\end{abstract}

Keywords: Businesses, foreign direct investment, Vietnam

\section{Introduction}

foreign direct investment is a way of market penetration which is developing recently of Vietnamese enterprises. It is proved that the stronger country's foreign direct investment flows, the more chances to expand its market, improve production efficiency, utilize interior sources, create employment opportunities and motivate economic development, as well as establish technology, accelerate management capacity and marketing level with not only regional but also global, this method is a way for companies to effectively preserve their capital. Lately, Vietnamese businesses' foreign direct investment projects, despite of small source of money, have brought certain success. The likelihood to promote manufacturing and business via overseas direct contribution at this period of time is huge and obviously creating favorable conditions for Vietnamese agencies. Although some of them have gained big success, the others are still confused on many aspects to perform their strategies. It can be said that foreign direct investment is a chance to take benefit for both business and nation, however, transforming opportunity to practice is a long process, requires Vietnamese companies to have equivalent position and ability to achieve positive result. Based on this practice, the writers are desired to share their point of view and make some recommendations about this subject.

\section{Literature Review}

Foreign Direct Investment (FDI) happens when an investor from a country have asset in another nation with its ownership. The management aspect is distinguish FDI from other financial instruments. In most cases, both of investor and their abroad asset are premises, in which, investors are often called "parent company" and assets are "subsidiary" or "branches" (WTO, 1996). According to OECD iL Library, Foreign Direct Investment (FDI) is a type of border-accrossed funding, in which an investor residing in one economy establishes long-term concern and the significant influence on a business in another economy. Investor's ownership of above $10 \%$ of voting roghts in a economic in other one is a proof of such relationship. FDI is not only a critical factor in economic intergration because it creates stable and long-term relation among economies, but also a significant channel to transfer technology among nations, promote international trade via approaching foreign market and perhaps a crucial expediency to develop economy. Mentioned indicators in this group are interior and exterior values for stocks, flows and incomes, based on partner countries and limits of industry and FDI.

The research of Faruk Ahmeti and Halil Kukaj (2016) told that FDI contribute host country's economy development in two main ways. First, they includes increasing interior equity and advancing outcome by transfering the latest technology, marketing and management skills, innovation and practice. Second, FDI has both benefit and expenditure, and its effect is determined by country's specific conditions in general and policies 
emvironment in particular. This fact is about diversification ability, absorption capacity level, targets FDI's aim and other chances to connect FDI and interior investment. FDI plays a role in increasing surplus of equity's account, improving balance of payment in general and stablize macro economic. Developing countries often have low accumulation fund rate, therefore, FDI is considered as important capital to implement interior investment aiming at economy improvement. FDI creates oppotunities for poor countries to easily approach advanced technology, transfer technology, boost knowledge popularization process, encourage management skills and qualifications, etc. This impact is considered as influencing FDI's productivity of interior businesses and contributing in economic development in general (Central Institute for Economic Management, 2006).

Xiaoying and Li Xiaming (2005) have pointed out endogenous relationship between FDI and economic development determined from the middle of 1980. FDI benefits economic development both directly and indirectly by interative terms. FDI's cooperation with human resources creates strong and positive effect to developing countries' economy development, meanwhile, FDI with technology's distance has significantly negative impact.

The research of Teivan Pettinger (2019) points outmain factors of FDI are wage, labor skills, tax rate, telecommunication and infrastructure, economic size/ potential, stable politic/property rights, merchandise, exchange rate, clustering, free-trade area approaching. Sajjad Afridi and Sajida Gul (2018) have considered factors of society, economy and infrastructure, in which the others are acknowledged such as trade, exchange rate, GDP, income per capita (economical factors), health and education (social factors), road, rail, phone and internet(infrastructure factors). Research's statistics are collected from Pakistan State bank, Pakistan's economic survey. The result reveals that there is a significant and considerable impact of economic and social element on FDI. Moreover, there is a trivial and negative relationship between infrastructure and FDI form 2005 to 2015. The research makes a conclusion that the government should focus on speeding up growth and encourage critical stability in the economy to bring interior FDI inflows. However, according to Nguyễn Thị Ngoc Mai's invesstigation (2016) asserts that export is the main component promoting Vietnam's FDI. Therefore, in the future, Vietnam government needs to be more concerned of export and income FDI to booste FDI inflows.

When studying FDI policies of China, Do Huy Thuong (2015) has learned that it is neccessary to evaluate a specific promoting strategy; competent management apparatus needs to be devolved to facilitate businesses; offshore investment licensing procedures and dossiers should be simplified, especially, complicated verification and verification process should be removed; under allowable conditions, to implement some financial support measures at a reasonable level. Japan has liberalized overseas funding, however, executed aborad investing policy in a reliable and calculated. Liberalisation overseas investment is made only when Japanese economy and businesses who have strong financial potential and production scale needs to expand their influence range worldwide in order to manufacturing capacity for domestic economy (Vũ Văn Chung, 2012).

Korean goverment, instead of developing policies and specific orientation for firms who invest abroad, lets the market regulate investment and business activities of the private enterprises group (invisible hand). In order to encourage and support foreign investment focusing on small and medium-sized enterprises (SMEs), Korean government has applied four big policies for business backing: (1) Financial support, mostly via Export-Import Bank of Korea Eximbank; (2) Up to $90 \%$ support of the total registered investment capital for SMEs; State Export Insurance Corporation guarantees direct and indirect investments; (3) Provide tax support and promote agreements on double taxation prevention and investment protection; (4) funding boosting support via Korea Trade-Investment Promotion Agency (KOTRA) mostly provides information and effectuates contribution advance activities to support small and medium-sized enterprises, ease and simplify regulations on offshore investment registration (Vietnam Foreign Investment Department, 2015).

\section{Method}

The writers mainly use descriptive statistical methods to analyse practice, result and limits of Vietnamese's businesses FDI situation. The statistics are collected and concluded from General Statistics Office of Vietnam, Vietnam Foreign Investment Department - Ministry of Planning and Investment of Vietnam throughout years, Report No. 499/BC-CP of Vietnam government in 2019.

\section{FDI Situation of Vietnamese Businesses}

\subsection{The Legal System of FDI in Vietnam}

In the early 90s, FDI infcome of Vietnam increases year by year, the number of fabric enterprises who invest overseas soared, therefore, annual export quota does not meet the production capacity. Moreover, prohibited law of logging and near-shore fishing for natural resources protection influence production and business activities of 
some enterprises in processing and consumer goods manufacturing industry. Therefore, some firms change their business goals or searching investing opotunities in regional countries. Among businesses pioneering in offshore investment, some private companies in localities in the border areas with Laos and Cambodian has performed investment projects there under bilateral cooperation agreement between local governments of two countries.

In Resolution No. 01-NQ-TW of November 18, 1996 on operation and improvement of foreign economic efficiency, Central Committee of the Communist Party of Vietnam has a policy of "taking steps to make foreign investments". In order to achieve this undertaking, on Apri; 14th, 1999, the government promulgated Decree no. 22/19999/NĐ-CP about foreign investment of Vietnam enterprises to introduce and manage every activities of abroad asset. It can be said that after 10 years of performing Vietnam foreign investment law (the first version in 1987), the law on offshore contribution in this country began to form, pave the way for FDI in the future. Although the legal framework for offshore investment of Vietnamese enterprises was issued in early 1999, before this time, some Vietnamese companies had already traded in other countries.

According to Decree 22/1999/NĐ-CP, Vietnamese enterprises who are allowed to invest abroad consist of: (1) enterprises established under the Enterprise Law of the State; (2) cooperative established under Cooperative Law; (3) enterprises established under Company Law; (4) enterprises established under Private enterprises Law. Contemporarily, enterprises have to catch up with the following conditions: (1) Foreign investment projects are possible, (2) financial capacity needs requirement of foreign investment; (3) Financial obligation to the State is fulfilled.

In order to implement Decree 22/1999/NĐ-CP, related minstries and department has promulgated guidance documents of foreign direct investment activities of Vietnam businesses (Appendix III). It can be said their formation has created basic legal corridor aiming at approving, controlling and instructing a brand-new activity of Vietnamese companies. Promulgated decree 22/1999/NĐ-CP and instructing documents have marked the milestone in firms in Vietnam's offshore investment policies, facilitated the advent of certain succeeded projects. It also witnessed the growth of Vietnamese businesses in the process of integration of regional and worldwide economy. However, their abroad investment activity has met confusion and difficulties when implementing.

From above-mentioned situation, in 2005, the government submitted to the National Assembly with an aim to legalize the law on abroad investment activities and has been approved by the National Assembly of the Socialist Republic of Vietnam, session XI, 8th session, on the Investment Law 2005 dated November 29th, 2005, effective from July 1st, 2006; however, only one chapter (chapter VIII) provides for offshore funding of Vietnamese enterprises. In a short period of time, Decree no. 78/2006/NĐ-CP of the government about foreign investment issued in August $09^{\text {th }}, 2006$ with 4 main objects which are (1) suitability to reality of operation; (2) more clear and specifically regulations; (3) State's management efficiency and (4) administrative procedures simplification. Contemporarily, it mentions inheritance and promotion of positive aspects, current legal system's disadvantages of FDI improvement in order to expand and develop freedom in business. The Decree also regulates investors and businesses of all economic sectors have the right to make a contribution overseas, to have autonomy and responsibility in business activities, to choose and change interior administrative organization, investment form corresponding with their demand and be protected by Vietnamese Law, considering guarantee process of multilateral and bilateral agreements in international economic integration.

Moreover, Decree 78/2006/NĐ-CP also mentioned about responsibility, relationships among state agencies, investors and businesses, about performing it as well as punishment when there is violation from both sides (investors and state agencies) when not obeying regulation of current law.

After 9 years of implementation, besides of above-mentioned results, Investment Law has revealed some limits which need to be amended and supplemented. In 2014, the National Assembly promulgated the new Investment Law to replace the 2005 version. Comparing with the old one, the new law has a lot of changes which are innovated and more suitable to Constitution year 2013 and international treaty where Vietnam is a member, create a solid basis for the State to effectively manage investment activities. Nonetheless, after one year of performing, Investment Law 2014 has revealed some limits which need need to be amended and supplemented. Until 2016, the National Assembly made a change and addition in Article 6 and Appendix 4 of business lines with condition of Investment Law 2014.

In order to perform Investment Law, the government and State agencies has promulgated legal documents for specifically guiding the implementation of the Law, contributing to bringing the law to reality. With current legal document system basically is fulfilled and completed to create constitutional corridor for effective investment activity.

Legal documents of current investment, besides of Investment Law of business of business and funding in and/or 
from Vietnam, has Decrees and 07 Circulars specifying and instructing this Law as follows:

- Investment Law No. 67/2014/QH13 in November $26^{\text {th }}, 2014$ of National Congress and No. 03/2016/QH14 in November 22nd, 2016 amended and supplimented Article 6 and Appendix 4 about a list of sectors and businesses subject with conditions of Investment Law.

- $\quad$ Decree No. 83/2015/NĐ-CP in September 25th, 2015 of the Government about international investment; Circular 09/2015/TT-BKHÐT in October 23rd, 2015 promulgated by Minister of Planning and Investment via document sample about offshore investment procedures performance.

- Decree No. 135/2015/ND-CP in December 31st, 2015 of the Government about international indirect investment; Circular 105/2016/TT-BTC in June 29th, 2016 of Minister of Finane, instructs international indirect investment activity of Securities trading companies, securities investment funds and insurance company; Circular 10/2016/TT-NHNN in June 29th, 2016 of Minister of Planning and Investment instructs some contents mentioned in Decre No. 135/2015/NĐ-CP in December 31st, 2015 of the Government about international indirect investment.

- Moreover, there are other laws and decrees, circular mentioned about investment activities. Especially documents of business investment conditions. Basically, the law system in investment is fulfilled and ensures effective business funding.

\subsection{The Current Situation of Vietnamese Businesses's FDI by the Time}

\section{- $\quad$ From 1989 to 1998}

From the Sixth National People's Congress of the Communist Party of Vietnam (December $15^{\text {th }}-18^{\text {th }}, 1986$ ), Vietnam economy started to have strong improvement. Economic sectors are free and equal to do their owwn business, gain revenue and be allowed to invest overseas. However, due to weak interior power, this activity, genrally, is very small in both quantity and quality. Therefore, in this period of time, the number of FDI projects are not much. Along with huge FDI inflows is a few offshore funding with small capital scale (Table 1). Vietnam's very first project is the foundation of Gemasa Corp Joint Venture (maritime service) in Japan which was licensed to operate in August 25th, 1989 with total equity of 563,380USD. However due to some objective reasons, this project was not deployed. Nonetheless, 1989 is still considered as a milestone to start the international investment activity of Vietnam (General Statistics Office of Vietnam and Foreign Investment Department - Ministry of Planning and Investment of Vietnam).

Table 1. Foreign direct investment from 1989 to 1998 (unit: milion usd)

\begin{tabular}{lllll}
\hline Year & Number of projects & Total investment & Authorized capital & Vietnam contributes \\
\hline 1989 & 1 & 0,6 & 0,6 & - \\
1990 & 3 & - & - & - \\
1991 & 3 & 4,0 & 4,0 & 2,0 \\
1992 & 4 & 5,4 & 5,4 & 2,3 \\
1993 & 5 & 0,7 & 0,7 & 0,4 \\
1994 & 3 & 1,3 & 0,7 & 0,4 \\
1995 & 0 & - & - & - \\
1996 & 0 & - & - & - \\
1997 & 0 & - & - & - \\
1998 & 2 & 1,9 & 1,9 & 1,6 \\
\hline
\end{tabular}

Source: General Statistics Office of Vietnam and Foreign Investment Department - Ministry of Planning and Investment of Vietnam.

In this period of time, there were only 21 FDI projects in Vietnam with total investment of 13.9 million USD. The average scale of investment for a project is still quite modest which is at 0.66 million USD. Every year, Vietnam only has some FDI projects with maximum 5 in 1993. Realised capital is low, there was not disbursement in some years. Investment projetcs are mainly seafood export, agriculture, mining in Laos, Russia and especially establising shipping agency, logistics in Singapore, england, etc. Investors mostly are State enterprises and major organisations. International investment in this period of time mainly aims at creating trade bound with countries where there are a lot of Vietnamese living or having a close relationship with Vietnam, serving import and export needs which are born after renovation.

- $\quad$ From 1999 to 2005 
In this period of time, Vietnam had 133 FDI projects with total regstered capital of 606.8 million USD; 6.3 times in terms of the number of project and 43.7 times in the total investment when comparing with the period of 1989-1998; the average funding scale was 4.6 million USD per project which is higher than the last duration. This is the stage that Vietnam bean to speed up its integration into worldwide economy, participation in more international organisation, offshore investment, and had many flourishes and expanded contribution since (Table 2). While new capital inflows from foreign countries to Vietnam in 2002 was declining, the ouflow from Vietnam to other nations increased unexpectedly(General Statistics Office of Vietnam and Foreign Investment Department - Ministry of Planning and Investment of Vietnam)

The highlight of 2002 is that there were more and more Vietnamese plastic firms invests abroad. With the ability to quickly capture the market, they realised that the need for plastic goods is increasing nonstop in Ukraina, Iraq, Russia, the U.S and African countries' market, especially in two original ones which are Laos and Cambodia (Plasstic goods of Vietnam accounts for almost $80 \%$ of market share), meanwhile export had not met the need or due to import limits, therefore, Vietnamese businesses had decided to build manufacture factory in above nations. In 2012, after Laos, Russia became top. 2 of attracting foreign investment from Vietnam with 10 projects of 17.36 million USD (Foreign Investment Department - Ministry of Planning and Investment of Vietnam)

The year of 2003 had many projects of investment in Laos and Russia. The biggest one in Laos is Sai Gon Plastic plan of construction of household plastic manufacturing factories with contributed capital of 1.31 million USD. The biggest contribution in Russia was ceramic tiles manufacturing project of Thach Ban company (Hanoi) with total investment of 16 million USD. Likewise, there were 2 plan of 9.4 million USD of Vietnam Oil and Gas Group for seismic and geophysical research in order to explore oil and gas in Indonesia; and tuynel brick factory construction project, with the capacity of 10 million bricks per year of Hanoi Construction Corporation in Vientiane,which is worth 652,000 USD (Foreign Investment Department - Ministry of Planning and Investment of Vietnam).

Table 2. Foreign direct investment from 1999 to 2005 (unit: milion usd)

\begin{tabular}{lllll}
\hline Year & Number of projects & Total investment & Authorized capital & Vietnam contributes \\
\hline 1999 & 10 & 12,3 & 6,8 & 3,4 \\
2000 & 15 & 6,7 & 5,6 & 3,4 \\
2001 & 13 & 7,7 & 7,6 & 5,4 \\
2002 & 15 & 170,9 & 156,2 & 153,7 \\
2003 & 26 & 28,2 & 27,7 & 26,1 \\
2004 & 17 & 12,5 & 9,7 & 9,6 \\
2005 & 37 & 368,5 & 133,5 & 131,3 \\
\hline
\end{tabular}

Source: General Statistics Office of Vietnam and Foreign Investment Department - Ministry of Planning and Investment of Vietnam.

From 2004, Vietnamese businesses started to explore brand new and potential market - The Czech Republic. The pioneer was Constrexim Holdings with investment project of 968.900 USD to The Czech Republic, with am aim at starting business at real estate, construction material production and import-export in this market. In the middle of September, 2004, Ministry of Planning and Investment of Vietnam continued to licensed a contributing plan of Tan Phu Cuong Chemicals Co. LTD (Ho Chi Minh city) with total investment of 100.000 USD, The enterprise specializes in manufacturing and trading garments. This project is intended to open garment distribution branch in this country and near-by market. The biggest project of 2005 is that of Viet-Laos Power (Hanoi) with total capital of 273,1 million USD to distribute $100 \%$ Vietnamese capital company in Laos which is called Xekaman Limited Liability Company. Moreover, the most awared plan in this year belongs to oil exploration and exploitation project in Malaysia, invested by Vietnam Oil and Gas group, deployed by of Petrol Investment and Development Company (Because in 2002, PIDC winned bid the project of oil and gas exploration and exploitation in Lot 433A and 416B in Southwest Algeria). In 22 years of operation in this majot in Malaysia, Vietnam Oil and Gas group holds $15 \%$ of participating benefits with a total contribution of 9.9 million USD. Along with this project is the other 2 includes financing plan to South Africa in the field of wood processing and supermarket business of Viet Trang company (Ho Chi Minh city) with 1 million USD capital; and project of searching and surveying salt in Laos of Vietnam National Chemical Group (Vinachem) with above 3 milion USD capital (Foreign Investment Department - Ministry of Planning and Investment of Vietnam).

Overall, the number of projects and total investment to foreign countries of Vietnam in this period of time 
increased over the years. The quantity of plans in 2005 boosted 3.7 times and total contribution developed 30 times that of 1999.

- $\quad$ From 2006 to now

Table 3. Foreign Direst Investment from 2006 to 2018 (unit: milion usd)

\begin{tabular}{lll}
\hline & Project quantity & Total registered capital (Million USD) $\left.*^{*}\right)$ \\
\hline 2006 & 36,0 & 221,0 \\
2007 & 80,0 & 977,9 \\
2008 & 104,0 & $3.147,5$ \\
2009 & 91,0 & $2.597,6$ \\
2010 & 108,0 & $3.503,0$ \\
2011 & 82,0 & $2.531,0$ \\
2012 & 84,0 & $1.546,7$ \\
2013 & 93,0 & $3.107,1$ \\
2014 & 109,0 & $1.786,8$ \\
2015 & 118,0 & 774,8 \\
2016 & 139,0 & 970,7 \\
2017 & 130,0 & 350,1 \\
Preliminary in 2018 & 155,0 & 477,6 \\
\hline
\end{tabular}

Note. $(*)$ counting only Vietnamese investors, including additional capital of licensed projects from previous years

Source: General Statistics Office of Vietnam.

Along with developing econommy, there are more and more Vietnamese enterprises have financial capability as well as experience to invest abroad. Moreover, they are also awared that benefits of FDI in the context of integration into regional and international economic life. Especially when Vietnam officially became the 150th member of World Trade Organisation (WTO), that has facilitated investment, and trading of companies, in which there is FDI (Table 3). In 2006, Vietnam had some big projects such as oil and gas exploration and exploitation in Singapore (21.94 million USD); rubber tree planting in Laos (12.54 million USD); a construction of Cho Ray Hospital - Phnom Penh in Cambodia (10.5 million USD); the venture of Southern Airports Services Joint Stock Company (Sasco) and HMSKY GmbH (Germany) to establish Nha Viet Joint Stock Company (Viethaus) in Berlin, Germany, in which Sasco contributed $50.5 \%$ of 5 million Euro equity; etc. Laos continued to head in receiving contribution from Vietnam, specifically, capital to Laos has increased in recent years when both sides have cooperated to promote many projects on infrastructure, energy and raw material area development. The telecommunication network construction in Cambodia of Viettel Group with 1 billion USD total investment and mall building in the U.S (30 million USD) of 584 group are considered to be a spectacular breakthrough of the year of Vietnamese enterprises. Also in 2006, Ministry of Planning and Investment of Vietnam licensed HOANG ANH Construction and Development house Joint Stock company (HAGL Group) to invest 20.4 million USD to Thailand with a name of HAGL-Bangkok Joint Stock Co. Ltd to implement apartment project in Bangkok (Foreign Investment Department - Ministry of Planning and Investment of Vietnam).

Following economic growth of previous years, Vietnam companies' FDI in 2007 flourished and thrived. I this year, there were 80 projects with total registered capital ò 997.9 million USD which is $222 \%$ of number of projects and $451.5 \%$ of registered equity higher than 2006. At the end of 2008, 4 FDI investment projects with 200 million USD of Vinamotor in Venezuela and Dominica became true. Every year from 2016 to 2018, there were almost 102 plans with average total registered capital of 1.692 billion USD per year. In which, in 2018, Vietnamese enterprises made the most investment abroad with 155 projects , and in 2010 they had the highest 
amount of capital for offshore funding with 3.553 billion USD total (Table 3).

\subsection{Current Situation of Vietnamese Enterprises' FDI by Economics}

Vietnam's FDI includes industry, agriculture and service; from industries with hgih labor content to that with high gray matter and techonogy content. Projects focused manily on mining (consists of oil and gas exploration and exploitation) (counts $39.40 \%$ of registered capital from Vietnam), agriculture, forestry and fisheries $(15.52 \%)$, telecommunication $(12.89 \%)$, electricity and gas production $(7.34 \%)$. The rest are manufacturing and processing, art, entertaining, real estate, banking and finance, trading, science and technology, etc. (Table 4).

About the number of project, Vietnam's foreign investment concntrate mainly on trading (counts for $27.90 \%$ total number of project), manufacturing and processing (10.67\%), agriculture, planting $(9.98 \%)$, media $(7.84 \%)$ (Table 4).

Table 4. Licensed FDI by economics (accumulation of valid projects until december 31st, 2018)

\begin{tabular}{|c|c|c|}
\hline & $\begin{array}{l}\text { Number } \quad \text { of } \\
\text { projects }\end{array}$ & $\begin{array}{l}\text { Registered capital (Million USD) } \\
(*)\end{array}$ \\
\hline TOTAL & $1.172,0$ & $20.247,7$ \\
\hline Agriculture, forestry and fisheries & 117,0 & $3.142,7$ \\
\hline Mining & 60,0 & $7.978,8$ \\
\hline Processing & 125,0 & $1.078,8$ \\
\hline $\begin{array}{l}\text { Manufacturing and distributing electricity, gas, hot water, steam and air } \\
\text { conditioner }\end{array}$ & 9,0 & $1.486,5$ \\
\hline Water supply; waste management and treatment & 2,0 & 0,6 \\
\hline Construction & 78,0 & 52,2 \\
\hline Wholesale and retail; motor vehicles repair & 327,0 & 464,1 \\
\hline Transportation, warehousing & 39,0 & 71,4 \\
\hline Accommodation and catering services & 67,0 & 197,8 \\
\hline Information and communication & 92,0 & $2.610,8$ \\
\hline Finance, banking and insurance & 23,0 & 821,7 \\
\hline Real estate & 41,0 & 870,2 \\
\hline Science and technology & 76,0 & 286,7 \\
\hline Administrative activities and support services & 44,0 & 67,9 \\
\hline Education & 11,0 & 3,0 \\
\hline Health and social assistance activities & 6,0 & 16,0 \\
\hline Art and entertaining & 7,0 & $1.016,5$ \\
\hline Other services & 48,0 & 81,8 \\
\hline
\end{tabular}

Note. $(*)$ Counting only the capital of Vietnamese investors including additional capital of licensed projects from previous years.

Source: General Statistics Office of Vietnam.

\subsection{Current Situation of Vietnamese Enterprises' FDI by Partners}

In 2017, some new plans which had registered capital over 10 million USD such as: the contribution in floating production storage and offloading (FPSO) for Talisman Vietnam 07/03 B $>\mathrm{V}$. Limited to serve the development of Red Arowana mine in Lot 07/03 Vietnam offshore of Petrol Technique Service company (PTSC) (Established in Marshall Island) (56.9 million USD); exploitation and process refining ores into gold and ferrous metal in Uganda of Ba Dinh CIC JSC (35 million USD); construction of houses for sale and for rent in Australia of IMG Investment Joint Stock Company (34.5 million USD). Moreover, there are some other projects such as 
repurchasing shopping mall and business and office premises demise in America of Dien Phuc Thanh Construction and Business Limited company (15 million USD); planting 939 hectares of passion fruit and 150 hectares of avocados in Laos of Hung Thang Loi Gia Lai Joint Stock company (12.5 million USD); business on wood and wooden products in New Zealand of Mr. Nguyen Hong Chuyen (10.23 million USD). Investment activities which increase their financial asset have additional capital over 10 million USD, consist of Military Commercial Joint Stock Bank MB Bank raising money for its branch in Cambodia (36 million USD); Vinamilk expanding fund of milk factory in Cambodia (10.78 million USD); Hoang Quan Education investment Limited Company rising cash for house renting in America (10 million USD) (Anh Mai, 2018).

According to Foreign Investment Department in 2018, Vietnam had invested to 38 nations and territories. In which, Laos was leading with $18.8 \%$ of total contribution, at 81.5 million USD. The second one is Australia with 55.5 million USD, took $12.8 \%$ of total. The third is America with 52.9 million USD, corresponding with $12.2 \%$ of total investment, the next are Cambodia, Slovakia, Cuba (Foreign Investment Department - Ministry of Planning and Investment of Vietnam).

Until December 31 st 2018 , markets which attract investment of Vietnam the most is Laos (accounts for 24.17\% of total registered capital from Vietnam), Russia (13.98\%), Cambodia (12.51\%), Venezuela (9.01\%), Myanmar $(8.11 \%)$, Singapore (7.5\%), the rest are Australia, Germany, Malaysia, etc. (Table 5). This indicates that Vietnam has integrated into worldwide economy with high speed, as well as continuous growth of businesses when deciding to not ignore contribution opportunities and potential markets.

Table 5. Current situation of Vietnamese enterprises' FDI by main partners

\begin{tabular}{lll}
\hline & Number of projects & Total registered capital (million USD) $\left(^{*}\right)$ \\
\hline TOTAL & $1.172,0$ & $20.247,7$ \\
In which: &.$\cdot$ &.$\cdot$ \\
Laos & 201,0 & $4.894,7$ \\
Russia & 15,0 & $2.830,7$ \\
Cambodia & 173,0 & $2.735,9$ \\
Venezuela & 2,0 & $1.825,1$ \\
Myanmar & 95,0 & $1.327,1$ \\
Angeria & 1,0 & $1.261,5$ \\
Peru & 4,0 & $1.249,0$ \\
Malaysia & 17,0 & 812,7 \\
The U.S & 160,0 & 636,9 \\
Tanzania & 4,0 & 356,3 \\
Mozambique & 3,0 & 345,9 \\
Singapore & 88,0 & 284,9 \\
Australia & 51,0 & 253,9 \\
Cameron & 3,0 & 230,7 \\
Republic of Burundi & 2,0 & 170,0 \\
Virgin Islands & 10,0 & 132,7 \\
Germany & 29,0 & 120,3 \\
Madagasca & 1,0 & 117,4 \\
\hline
\end{tabular}

Note. $(*)$ Counting only the capital of Vietnamese investors including additional capital of licensed projects from previous years.

Source: General Statistics Office of Vietnam 


\subsection{Current Situation of Performing FDI Projects of Vietnamese Businesses}

Until December 31 $1^{\text {st }}, 2018$, 19 State-owned enterprises and enterprises with dominant state capital (The State holds more than $50 \%$ of authorized capital) had offshore investment. They implement their contribution in 114 projects, mainly in media, oil and gas exploration and exploitation, rubber tree planting, mining and banking-financing. Total registered capital was 11.964 million USD, in which there are 3 biggest group, including: Vietnam Oil and Gas Group (6,677 million USD, takes 56\%), Viettel group (2,992 million USD, takes 25\%), Vietnam Rubber Group (1,429 million USD, takes 12\%) (Report no, 499/BC-CP of Vietnam Government, 2019).

In 2018, businesses had paid 194 million USD abroad. Accumulated to December 31, 2018, total realized investment capital of 19 enterprises was 5,817 million USD which takes $48.62 \%$ of total registered abroad investment capital. Petro Vietnam has the largest porportion at $49 \%$ with accumulated financing of 3,032 million USD. The second one is Viettel with 1,606 million USD (26\%) and the third belongs to VRG with 923 million USD (15\%). The rest of the money is for abroad contribution with registered capital of above projects is 6,148 million USD (51.39\% out of registered abroad capital) (Report no, 499/BC-CP of Vietnam Government, 2019)

Regarding the payback situation in 2018, , the projects revoked 559 million USD, in which $60 \%$ is $60 \%$ is investment eviction (333 million USD), $38 \%$ is repatriation profits ( 212 million USD), $2 \%$ is interest collection from lending money to projects overseas (14 million USD). Accumulated to December 31st, 2018, 6 out of 19 businesses has had their payback from offshore funding with total amount of 2,594 million USD, corresponding with $45 \%$ of realised capital. There were 84 out of 114 overseas projects gaining 4,158 million USD of total revenue (4\% less than that of 2017) and 187 million USD of total profit (24\% less than that of 2017) (Report no, 499/BC-CP of Vietnam Government, 2019).

Total incurred loss of projects is 367 million USD (265\% more than that of 2017) in which the highest proportion belongs to Viettel with 349 million USD, the second is 7.7 million USD. According to the Government's appraisal, fields of telecommunication, petroleum business, oil and gas service,constructing and lodging take $60 \%$ of the project generating interest. By contrast, fields of searching, exploring and exploitation of oil and gas and mining have low interest proportion, respectively at $17 \%$ and $11 \%$. Moreover, fields of telecommunication, planting and processing latex and mining have many projects suffering from accumulated losses with 11, 22 and 6 projects (Report no, 499/BC-CP of Vietnam Government, 2019).

Remarkably, when comparing with 2017, revenue and profit growth of 2018 in most fields decreased. In which, the loss in revenue mostly from mining (27\% down) and oild and gas business ( $23 \%$ down) due to the fluctuation of world oil price. Profit had the biggest drop in not only telecommunication with 349 million USD loss due to devaluation of the local currency, inflation in invested countries (in Africa, Central America or South East Asia) and intense competitiveness; but also latex planting and processing (over $40 \%$ down) due to serious shrinkage of world natural rubber prices and the influence of host countries changing investment and land policy (Laos, Cambodia) (Report no, 499/BC-CP of Vietnam Government, 2019).

\section{Result}

Along with enhacement the attraction of FDI into Vietnam, offshore investment trend of Vietnamese businesses is expanding. This is a risky direction, however, neccessary if they desire to approach world market. In Vietnam, there are a lot of companies gaining success in the following aspects:

About policies, laws and State management activity of Vietnam:

- Vietnam's law and policy system about FDI is getting improved, creating legal framework fro operating and managing FDI

- Banking and Insurance's freedom in offshore investment is very important to their own development and the close relationship with investors in other fields. Bank's abroad expansion support businesses in fund raising, overseas money transfer, profits remittance to investor and finance support. This is often seen in countries when a business have their contribution in foreign nations, other companies follow and receive service contracts which is the same as in host countries with investors such as banks, advertisement service, support, etc.

- Vietnam has economical and trade relationship with over 200 countries and territories, most of which promulgating FDI encouraging policies. Especially, the affair between Vietnam and some economy (Laos, Russia, Cambodia, China, etc.) is favored by the Government to investment cooperation of both sides' businesses. Besides, the relation between abroad ambassador and FDI companies is getting closer and closer.

- The agreements, protocols, agreements, interior and exterior legal institutions directly related to investment, goods transportation, service and labor across national borders play an important role in Vietnam's contribution 
outflows to foreign countries. This is a try of the Government which allows Vietnamese businesses to approach deeper and wider to offshore market in order to diversify and constantly add, expand the range of partners, raw material market, technology, materials and customers, etc, therefore allows to broaden capital inflows into the country originating directly from profit repatriation earned from offshore investment, or from the results of enterprises' direct investment assisstance with foreign partners.

- FDI has partly reveals Vietnam's power in not only economic but also politic creating close relationship with host countries and advance national prestige in international arena. Thanks to FDI, Vietnamese businesses can make use of their capital more effectively, ensure their financial capacity, therefore, have a good performance in financial obligation and take part in State Budget, increase capital for national economic development.

To Vietnamese businesses:

- Limits about capital, technology and experience in abroad investment when realting to other businesses in Asia have been boosted up by Vietnamese companies via promoting comparative advantage from products which have inherent strength such as food processing, textiles, shoes, handicrafts, plastic, wood gathering, agricultural, sea food, ceramics, household appliance, materials building.

- Vietnamese firms know how to choose reasonable investment area, market segmentation and deeply integration into target markets (Laos, Cambodia, Russia, etc.); dare to implement projects which is risky but effective into large and fastidious markets such as America, Europe and Japan.

- In high-tech industry requiring huge amount of capital, branches appear overseas under the form of agencies distributing products to groups, processing each stage of the product, or proceeding offshore investment. Those activities help them with not only efficient abroad funding but also collecting valuable technological information to serve domestic manufacturing.

- Contributing in markets such as Russia, America, Europe, and Australia where large Vietnamese community is available allows businesses to make use of capital, gray material, multi-dimensional, multi-level and useful relationships in countries at present and in the future. That has directly increased the promotion of Vietnamese science and people in those markets in particular and in world market in general; leaded to the opening of investment opportunities, jobs, abroad studying and education for Vietnamese in both hometown and overseas.

- Vietnamese businesses have created good relationships with companies and authorities in host countries. They have facilitated projects to be implemented as soon as possible. When funding in developed economies, enterprises have gained experiences and approached advanced management level and high technology.

- Foreign investment (setting up representative office, branches, consuming agents, establishing direct factories, etc.) has helped companies to actively build their own merchandise distributing system, advance marketing, make use of available appliances and labor, as well as catch up with local market's movement, needs and trend, therefore, make the best decisions in their own business.

- Increasing abroad investment also means opening more networks, channels and economical - social relationships between Vietnam and foreign markets, therefore, capital flows, science, technology and labor enhance two-way flow, bring new and positive impulse to domestic economy and society development; facilitate Vietnam in its interconnection and integration into international life pace, ensure coherence, unity between manufacturing and consumption of businesses in current globalization trend.

\section{Disadvantages}

About Vietnam's policies, law and administrative activities:

- The Government has not had specific policy to encourage Vietnamese businesses to invest in old markets, especially Laos, Cambodia and Russia

- Market investigation is limited, leading to lack of market information, policies and investment procedures of some nations and territories, thus, promotion and encouragement companies to contribute abroad meets difficulties.

- Legal documents relating to foreign investment is poor and have not embraced all of arose problems such as opening office in the third country to operate abroad projects, or branch to produce and establish offshore firms of companies having overseas capital.

- Administrative activities of abroad investment after being licensed meets difficulties due to unfulfilled reporting regime of businesses while sanctions are not clearly defined and strictly implemented. 
To Vietnamese businesses:

- The way to invest in foreign countries is not eassy, because large and new market always risks which even big economical groups when dealing with have to stagger. Therefore, dificulties and limits in the first time of Vietnamese businesses is unavoidable.

- Limits in capital: A lot of money needed for abroad investment is a factor which have to be considerated of businesses. Weak ability and lack of management experience lead to low competitiveness when comparing with same manufacturing sector enterprises in host countries. Little of capital makes some projects survive in a short period of time since production is stagnant and intetmittent, which makes investors discontinue to implement their projects. The plans $100 \%$ Vietnam capital fund-raised has interfered companies who has been fresh in new investment environment. Their being done in this form leads to loose relationship between them and host countries' authorities, companies and market while implementing their projects.

- Small number of projects and investment scale: except for art, entertainment who have average capital of 145.21 million USD/project; electronic producing and distributing (165.17 million USD/project); mining (132.98 million USD/project), the others have not had large scale invesment projects (Tale 3). Small range of funding leads to difficulties for businesses when there is no protection from the State, in front of the pressure of competitors who is financial potential in both host market and world market.

- Fields of banking, finance, insurance play an important role in supporting foreign investment such as lending, financial leasing, transfer of capital abroad or profits back to Vietnam. However, not many companies who contribute abroad (23 projects with total investment of 821.7 million USD) (Table 4).

- Additional cost consuming: Most of businesses suffering from additional expenses when investing abroad because domestic lawyer for advice is hard to be found, companies have to hire foreign ones who want high price. Another expenditure is that most of firms does not have auditing report, therefore, each audit phase is time and money-consuming because $t$ is compulsory requirement due to foreign currency security.

- Labor: Bring people abroad is a big obstacle. This problem is harder to deal with since difficult relies in both Vietnam and the host country. Moreover, the rumor about Vietnamese's escape after being allowed to enter the country makes the authorities in many countries hesitate. Businesses must make a commitment with host countries' goverment to ensure strict management to their people.

\section{Reasons}

Objective reasons:

- First to be mentioned is the effect of world economy fluctuation to Vietnam's in its interigation into every aspects, in which there are some global variation that is out of Vietnam's control.

- Competitive environment has not been healthy, consumer habits are still different in nations and territories contributed by Vietnam companies, which cause many obstacles.

- Most countries considers Vietnam is "the country transitioning to a market economy", the result is that host countries impose very high tax rate on Vietnamese goods. The policies and solutions against this kind of discriminatory dumping not only make a huge amount of goods due to high taxation that not only forces investors to withdraw from the host market, but also reduces competiveness in Vetnam's invested aspects. Furthermore, world's market price always fluctuates so that businesses suffer difficulties when approaching intended markets.

- Law system relating to investment of some countries and territories that Vietnam wants to make a contribution in is always in the process of modification and completion, thus, have a lot of changes.

- Labor force in some countries is limited, low-qualified, low at discipline and diligence, so that it is hard to meet the needs of investors demand for labor in both quality and quantity.

- Language difference is also one of the obstacles in Vienamese businesses' abroad investment.

Subjective reasons

- About macro-management, Vietnam has not had an overall national strategy about foreign investment in its integration into world economy. In general, this kind of contribution still relies on the realtionship among governments and localities.

- In reality, Vietnam has not create direct legal relationships with many countries in order to implement activities of economic - trade - bilateral investment according to current international standards, rules and routine. Moreover, Vietnam has not been official member of many organisations and International business legal 
institutions, which means that Vietnam is facing the requirement of fulfilling domestic and international legal gaps in order to create more and more improved investment environment based on the requirements of market economy development and international economic integration.

- Vietnamese businesses operates individually and fragmentely, even compete unfairly with each other; there is no connection to raise the voice to host countries authorities. Some companies violate their law, leading to discredit Vietnam investors.

- There has not been a website connecting to professional consulting organization nationwide and worldwide to provide services supporting offshore investment such as: market information (quality, price, supply and demand, product potentiality); partners' information, business chance and experience; investment environment (legal provisions, import and export procedures, requirements and certifications about product's safety and quality, cultural characteristics, consumer tastes, goods distribution system, etc.); trade promotion services (fair, exhibition, advertisement, events and market sightseeing, brokerage and contact with potential partners, etc.); judicial support service about signing up and handle disputes of trademark, audit and tax advice, etc.

- Most of Vietnam commercial bank has not had branches and representative office abroad or in big international financial centers in order to directly supply services of payment, money-transferring, insurance and credit guarantee (including international credit guarantee, mortgage with domestic assets) for Vietnam businesses investing overseas.

- The promotion of setting up bonded warehouses in foreign countries to not only increase direct sales to foreign partners, competitiveness and extension of goods distributing channels, circulation and trade of goods and services between domestic and international market; but also stimulate businesses to invest abroad, has not been encouraged yet.

\section{Recommendations for the Promotion of Vietnam Foreign Direct Investment in Its Integration into International Economy}

\subsection{Implications about State's Strategies and Policies}

- Vietnam needs to develop overall national strategy on offshore investment

In developing countries, foreign investment aims at cooperation in order to overcome capital shortage, take advance of overseas technology and gray materials, gain management experience, etc., which takes part of domestic economy development. Therefore, the Government (via Ministry of Planning and Investment) needs to develop overall national strategy on offshore contribution. It serves as a guideline for State management and determination of enterprises' abroad plans. Based on it, the State will set up preferential policies to encourage foreign funding in each specific time and field. The strategic plan also needs to point out the goals in each period, ensure businesses to be assured of long-term investment. Furthermore, it has to combine domestic investment attraction and offshore contribution in national overall development. Setting up a strategy about foreign funding is an important solution in the new period of globalization and an indispensable path for Vietnam to gain initiative in its integration into global economy.

- Vietnam needs to accomplish policies and law of FDI in accordance with international practices

Specific policy: the Government needs to have specific policies to encourage Vietnamese businesses to invest in not only old markets such as Laos, Cambodia, regional countries and Russia; especially Laos and Cambodia for labor training due to lack of quantity and quality; but also potential markets such as Latin America, Africa and Middle East despite facing with initial risks.

The Government needs to determine list of prioritized projects are in the fields of energy, exploitation of natural resources, especially exploration and exploitation of oil and gas and other minerals, industrial crops planting. Moreover, FDI projects if meet domestic needs of materials for production, should be taken into encouraged and supported categories.

Administrative procedures should be improved: registration or verification process, certificate for FDI projects issuing process need to be less time-consuming. Administrative procedures continue to be improved in a simpler and more convenient way, increase business' initiative and self-responsibilities.

- Vietnam should supply information to Vietnamese businesses who invest abroad

Ministry of Planning and Investment of Vietnam ought to cooperate with related ministries to organize collecting information in order to annually compile handbook providing domestic businesses and enterprises aiming at abroad contributing about: 
(1) Policies to attract investment, law relating to investment, manufacturing and business of host country' companies;

(2) Potential and oppotunities of investment in some specific aspects in host country;

(3) Specific funding projects have reached an agreement of both sides;

(4) Projects calling for foreign investment from host countries;

Programs promoting investment and market research to learn contributing environment and places, oppotunities and macroeconomic information in order to lead Vietnamese businesses to effectively invest there, need to be implemented. Moreover, it is a rush to develop a website connecting to worldwide professional consulting organization to provide services supporting offshore investment and judicial backing service about signing up and handle disputes of trademark.

\subsection{Implications about Vietnamese Businesses}

\section{- Vietnam businesses need to improve competitiveness}

In the harshness of the market economy recently, along with the contribution of world's economic giant which makes Vietnam economy be considered as miniature of international economic activities, enterprises have to determine right goods and market strategies, therefore, production and administration technology is renewed, ISO standards is applied, mode of operation is accomplished, business's own characteristics is formed, thus, it can catch customer's eye, develop their status and build their trademark.

Businesses should dare to invest in order to bring grey materials to their company. A right human ressources strategy may strengthen business' competitiveness interior and exterior relying on human's creativeness.

Long-term strategies on the base of precise evaluation target market and reputation remaining and business's trademark need to be oriented and built.

- Research and exploitation of potential markets

Vietnam foreign direct investment is later than other countries in the region who have equivalent potential. Therefore, it is a rush to make a research and facilitate companies to find out potential markets to create a certain advantage to nations coming later. The Africa is considered as a new, promising and easy-going environment for Vietnamese businesses to integrate in the context of America and the Europe markets is increasingly fierce, with many barriers such as quota, quarantine and anti-dumping.

Lately, Middle East countries are in great demand for many items which are Vietnam's strength such as fabrics, shoes, seafood, wooden products, agricultural products. However, Vietnam's goods, when entering this region, often have higher price than that of China, Thailand and India due to lack of two-way shipping. Success when investing in this area relies on competitiveness and the taking advance of barter business.

Another potential market in ASEAN region except for Laos is Cambodia. Although this is a poor country, it has large market due to being a member of WTO.. Moreover, Cambodia is supported in Generalized System of Preferences (GSP) from Japan, the U.S (6000 items), European Union, Canada, Australia. Vietnam companies can completely take advance of this advantage of Cambodia by joint venture to export to the thí country. The combination of Vietnam's capital and technology and Cambodia's labor, nature resouces and above benefits can produce low-price but high-qualified goods to compete.

- International marketing strategies planning

Vietnmamese FDI businesses should establish a specific marketing department in their own organizational structure. It is a need for them to take aware of each market's characteristics to have suitable economical policies. Trademark protection and marketing strategies planning abroad is neccessary and critical to market approaching and intergrating and direct investment implementing.

- Mobilizing and accumulating capital to expand reinvestment, increasing competitiveness in international market

The capacity of Vietnamese enterprises in terms of capital is not strong, besides the management experience is limited so the competition for firms doing business in the same field in host country is very fierce.therefore, they need to increase equity accumulation to expand reinvestment, increase competitiveness in international market; apply all forms of raising capital by many methods, in which financial publicity should be done to be gradually listed on stock market, in order to be active in equity sources research and market exploitation; find out the way to reach and make use of capital support from global organisations of abroad investment of companies belonging to private sector. 


\section{- $\quad$ Approporate investment form choices}

There are many forms of foreign direct investment, however, not all of them is suitable to Vietnamese companies. Therefore, they should be careful when deciding what type brings the highest effect. Recently, joint venture is the most favorite one, next is business cooperation contract; nonetheless, form of $100 \%$ foreign capital, despite of certain limits, is prefered by Vietnamese companies in order to manage the projects themselves. It is often applied for small and medium plans which suitable for fledgling financial ability of Vietnamese firms, expecially private ones. Contributing fields that often use this form are those which require little capital or low risk such as light industry, food industry, agro-forestry, tourism and services such as investment advisory and trade support. Joint venture when being practiced helps companies decrease the risk of approaching new market. Experience of China, Taiwan and Thailand shows that in the beginning period of abroad investment, businesses in those countries often prefer joint venture than $100 \%$ capital contribution so that they can take advance of market familiarity and laws in host country and decrease expenditure. However, this form does not come uo to expectation because dispute happens. Business cooperation contract is often the result of the collaboration between Vietnam government and hót countries' via agreements. This type has initially been quite effective, brought huge benefit to Vietnam by receiving preference from host country's government. Besides, Vietnamese firms should apply BOT form in old partners such as Laos and Cambodia in infrastructure development projects.

- Taking advantage of permanent residence rights in some developed countries

One of permanen concerns of successful entrepreneurs in Vietnam is how to compete with their peers abroad. In other words, if they have the same developmental conditions as those partners, they can directly expand their business directly in major markets like North America and Western Europe. Currently, many very successful entrepreneurs in the country desire to find a way to expand their business worldwide despite of some obstacles. For example, export and goods consumption depends on foreign partners because they cannot import into those markets themselves; complicated procedures of obtaining a visa to enter those countries cause delay and make business miss their oppotunities when they need to quickly attend events such as fairs or exhibitions. a long marketing campaign to effectively reach customers quickly attend events such as fairs, exhibitions and long marketing campaigns to effectively reach customers. The same problems can be completely overcome if the entrepreneurs know how to take advantage of their particular direction and opportunity that their colleagues have used for a long time. Specifically, some developed countries such as Canada, Australia, allow foreign citizens to own permanent residence via investment or business. A lot of bussinessmen from countries such as China, HongKong, Singapore and Malaysia have taken avantages from this right in recent years, enjoyed favorable conditions and improved their reputation to expand business effectively from both foreign markets and native markets.

\section{Conclusion}

Foreign direct investment is a fundamental feature of the world's current economy. Developing and underdeveloped countries are completely capable and have many opportunities to contribute abroad, even into developed ones, if businesses are actively, creative and know how to seize the opportunity. Moreover, FDI facilitates companies to improve themselves, play a role in economy's development and accomplishing national economical policies.

\section{References}

Anh, M. (2018). In 2017, most foreign investment projects did not use state capital. Retrieved from https://nhadautu.vn/nam-2017-hau-het-cac-du-an-dau-tu-ra-nuoc-ngoai-khong-su-dung-von-nha-nuoc-d101 63.html

Anh, P. (2013). The effect of FDI to Vietnam's economy. Retrieved from http://www.vjol.info/index.php/khxh/article/view/32633

Bao, N. (2002). Foreign direct investment in China from 1979 to now. Hanoi: Science and Society Publishing.

Central Institute for Economic Management. (2006). The effect of Foregin Direct Investment to Vietnam's economy development. Project SIDA Improvement of the capacity of policy research to implement Vietnam's socio-economic development strategy from 2001 to 2010. Retrieved from http://www.ciem.org.vn/Portals/0/CIEM/BaoCaoKhoaHoc/2005/RRFDITang_truong_KTvietnamese_233.p $\mathrm{df}$

Circular no.09/2015/TT-BKHĐT of Minister of Planning and issue model document for offshore investment procedures $2015(\mathrm{Vn})$. 
Circular no.105/2016/TT-BTC of The Minister of Finance guiding foreign indirect investment of securities trading organizations, securities investment fund, Securities investment companies and insurance business $2016(\mathrm{Vn})$.

Chung, V. (2012). Abroad investment capital management: Lessons learned from Japan and Korea. Retrieved from https://cafef.vn/vi-mo-dau-tu/quan-ly-von-dau-tu-ra-nuoc-ngoai-kinh-nghiem-tu-nhat-ban-va-han-quoc-201 20512092827360.chn

Decree no. 22/1999/NĐ-CP of the Government about Vietnamese businesses' foreign investment (1999) (Vn).

Decree no.78/2006/NĐ-CP of the Government about foreign direct investment (2006) (Vn).

Decree no.83/2015/NĐ-CP of the Government about foreign investment (2015) (Vn).

Decree no.135/2015/NĐ-CP of the Government about indirect foreign investment 2015 (2016) (Vn).

General Statistics Office. (2018). Licensed foreign direct investment from 1989 to 2017. Retrieved from https://www.gso.gov.vn/default.aspx?tabid=716

General Statistics Office. (2018). Foreign direct investment is granted for licenses by economic sector (Accumulation of valid projects until 2017, December 31). Retrieved from https://www.gso.gov.vn/default.aspx?tabid=716

General Statistics Office. (2018). Foreign direct investment is granted for licenses by major investment partners (Accumulation of valid projects until 2017, December 31). Retrieved from https://www.gso.gov.vn/default.aspx?tabid=716

Friedrich, S., \& Bruno, S. (1985). Economic and political determinants of foreign direct investment. World Development, 13(2), 161-175. https://doi.org/10.1016/0305-750X(85)90002-6

Ha, V. (2019). Total registered abroad investment capital of Vietnam reached nearly 12 billion USD. Retrieved from

http://vneconomy.vn/tong-von-dang-ky-dau-tu-ra-nuoc-ngoai-cua-viet-nam-dat-gan-12-ty-usd-2019101715 4538213.htm

Hosein, S., \& Maryam, M. (2012). The Impact of Exchange Rate Volatility on Foreign Direct Investment in Iran. Procedia Economics and Finance, 1, 365-373. Retrieved from https://doi.org/10.1016/S2212-5671(12)00042-1

James, C. (2020). Foreign Direct Investment (FDI). Retrieved from https://www.investopedia.com/terms/f/fdi.asp

Kien, T. (1998). Key to advance marketing ability and competitiveness of Vietnamese business. Ha noi: Statistical Publishing House.

Kimberly, A. (2020). Foreign Direct Investment How FDI Affects Your Life. Retrieved from https://www.thebalance.com/foreign-direct-investment-fdi-pros-cons-and-importance-3306283

Law no.59/2005/QH 11 of National Assembly of the Socialist Republic of Vietnam Investment Law 2005 (2006) $(\mathrm{Vn})$.

Law no. 67/2014/QH 13 of National Assembly of the Socialist Republic of Vietnam Investment Law 2014 (2015) $(\mathrm{Vn})$.

Law no.03/2016/QH14 of National Assembly of the Socialist Republic of Vietnam amended and supplemented Law Article 6 and Appendix 4 on the list of sectors and trades subject to conditional business investment of Investment Law 2016(2017) (Vn).

Loan, L., \& Hien, N. (2020). Supporting Vietnamese enterprises to invest abroad. Retrieved from http://consosukien.vn/ho-tro-doanh-nghiep-viet-nam-dau-tu-ra-nuoc-ngoai.htm

Mai, N. (2016). Factors promoting Vietnam FDI. Vietnam Economic and Development Magazine, 225, 65-72.

Ministry of Planning and Investment of Vietnam. (2018). Report of foreign direct investment in 2018. Retrieved from http://www.mpi.gov.vn/Pages/tinbai.aspx?idTin=41920\&idcm=208

Ngoc, N. (2020). Hoạt động đầu tu của Việt Nam ra nước ngoài: The reality and recommendations. Retrieved from https://baomoi.com/hoat-dong-dau-tu-cua-viet-nam-ra-nuoc-ngoai-thuc-trang-va-khuyen-nghi/c/33790202.e 
pi

Report no.499/BC-CP of the Government about investment and usage of State's capital in enterprises ntionwide and the management and use of the Enterprise Arrangement and Development Fund in 2018(2019) (Vn).

Sajjad, A., \& Sajida, G. (2018). Factors Affecting Foreign Direct Investment in Pakistan. Retrieved from https://translate.google.com/translate?hl=vi\&sl=en\&tl=vi\&u=https $\% 3 \mathrm{~A} \% 2 \mathrm{~F} \% 2 \mathrm{Fwww}$. researchgate.net $\% 2 \mathrm{~F}$ publication\%2F324862243_Factors_Affecting_Foreign_Direct_Investment_in_Pakistan\&anno=2\&sandbox $=1$

Tejvan, P. (2019). Factors that affect foreign direct investment (FDI). Retrieved from https://www.economicshelp.org/blog/15736/economics/factors-that-affect-foreign-direct-investment-fdi/\&p $\mathrm{rev}=\mathrm{search}$

Thuong, D. (2015). China's Abroad Investment policies and lessons learned for Vietnam. Science Journal of Vietnam National University: Economics and Business, 31(4), 30-38.

Tuan, T. (2019). Overseas investment of Vietnam has increased sharply. Retrieved from http://tapchitaichinh.vn/nghien-cuu-trao-doi/dau-tu-ra-nuoc-ngoai-cua-viet-nam-tang-manh-314593.html

Vietnam Foreign Investment Agency. (2015). Korea's foreign investment trend. Retrieved from https://dautunuocngoai.gov.vn/tinbai/4159/Xu-huong-dau-tu-ra-nuoc-ngoai-cua-Han-Quoc

WTO. (1996). Trade and foreign direct investment. Retrieved from https://www.wto.org/English/news_e/pres96_e/pr057_e.htm

Xiaoying, L., \& Xiaming, L. (2005). Foreign Direct Investment and Economic Growth: An Increasingly Endogenous Relationship. World Development, 33(3), 393-407. Retrieved from https://doi.org/10.1016/j.worlddev.2004.11.001

\section{Copyrights}

Copyright for this article is retained by the author(s), with first publication rights granted to the journal.

This is an open-access article distributed under the terms and conditions of the Creative Commons Attribution license (http://creativecommons.org/licenses/by/4.0/). 